\title{
Corporate social (ir)responsibility: an analysis of the disaster in Mariana-Brazil
}

\author{
Mirian Albert Pires ${ }^{1}$ \\ Luciana Mourão ${ }^{2}$ \\ Fátima Bayma de Oliveira ${ }^{3}$ \\ Jose Antonio Puppim de Oliveira ${ }^{34}$ \\ 1 Universidade Federal do Espírito Santo / Department of Accounting, Vitória / ES - Brazil \\ 2 Universidade Salgado de Oliveira / Graduate Program in Psychology, Niterói / RJ - Brazil \\ ${ }^{3}$ Fundação Getulio Vargas / Brazilian School of Public and Business Administration, Rio de Janeiro / RJ - Brazil \\ ${ }^{4}$ Fundação Getulio Vargas / São Paulo School of Business Administration, São Paulo / SP - Brazil
}

\begin{abstract}
The issue of corporate social irresponsibility (CSIR) has gained prominence in world literature. This study analyzes the 2015 environmental disaster caused by Samarco Mineração S.A. in Mariana (MG), Brazil, as an example of CSIR. The objective was to understand whether the population's social identification with the company, which is translated into the economic benefits, reduced punitive intention, and blame attribution. The research instrument uses scales with psychometric indicators applied to 1,616 individuals. It was verified that the benefits to the local economy reduced the punitive intention in the municipalities of Anchieta and Guarapari (ES), and Mariana (MG). This was not the case for Colatina and Linhares (ES). Also, it was observed that the disaster's severity increased blame attribution, and the punitive intention increased the intention to engage in negative word-of-mouth (WOM) about the company. As the main conclusion, people were less likely to punish the company in the municipalities where it generated economic benefits. Keywords: corporate social irresponsibility; economic benefits; blame attribution; punitive intention; environmental disaster.
\end{abstract}

\section{(Ir)responsabilidade social empresarial: uma avaliação do desastre de Mariana-MG}

A temática irresponsabilidade social empresarial (IrSE) ganhou destaque na literatura mundial. No Brasil, o desastre causado pela Samarco Mineração S.A. em 2015 foi alvo de repercussão, constituindo uma oportunidade para estudar a IrSE. O objetivo deste estudo foi investigar se a identificação social com a empresa, que surge em função dos benefícios econômicos, reduz a intenção punitiva e a atribuição de culpa. O instrumento de pesquisa contém escalas com indicadores psicométricos aplicados a 1.616 indivíduos. Constatou-se que os benefícios para a economia local reduziram a intenção punitiva nas cidades de Anchieta-ES, Guarapari-ES e Mariana-MG. O que não ocorreu nas cidades de Colatina-ES e Linhares-ES, que não recebem benefícios econômicos, mas foram afetadas pelo desastre. Identificou-se, ainda, que a severidade do evento aumentou a atribuição de culpa e a intenção punitiva aumentou a intenção de comentários negativos. Como principal conclusão, onde a empresa gerou benefícios, as pessoas estavam menos propensas a puni-la. Palavras-chave: irresponsabilidade social empresarial; benefícios econômicos; atribuição de culpa; intenção punitiva; desastre ambiental.

\section{(Ir)responsabilidad social empresarial: evaluación del desastre de Mariana-MG}

La temática irresponsabilidad social empresarial (IrSE) ganó prominencia en la literatura mundial. En Brasil, el desastre causado por Samarco Mineração S.A. en 2015 fue objeto de repercusión, constituyendo una oportunidad para estudiar la IrSE. El objetivo de este estudio fue investigar si la identificación social con la empresa, que surge en función de los beneficios económicos, reduce la intención punitiva y la atribución de culpa. El instrumento de investigación contiene escalas con indicadores psicométricos aplicados a 1.616 individuos. Se constató que los beneficios para la economía local redujeron la intención punitiva en las ciudades de Anchieta, ES; Guarapari, ES y Mariana, MG. Lo que no ocurrió en las ciudades de Colatina, ES y Linhares-ES, que no reciben beneficios económicos y fueron afectadas por el desastre. Se identificó además que la severidad del acontecimiento aumentó la atribución de culpa y la intención punitiva aumentó la intención de comentarios negativos. Como conclusión, donde la empresa generó beneficios, la gente estaba menos propensa a castigarla.

Palabras clave: irresponsabilidad social empresarial; beneficios económicos; atribución de culpa; intención punitiva; desastre ambiental. 


\section{ACKNOWLEDGMENTS}

The authors thank to Coordination for the Improvement of Higher Education Personnel (CAPES).

\section{INTRODUCTION}

Corporate Social Irresponsibility (CSIR) is an emergent concept connected to the theme of Corporate Social Responsibility (CSR) (Alexander, 2015; Kotchen \& Moon, 2012; Popa \& Salanță, 2014). CSIR, however, is rarely explicitly discussed in the literature on CSR (Lange \& Washburn, 2012), suggesting the need for more and in-depth research.

Armstrong (1977, p. 185) states that "a socially irresponsible act [...] involves a gain by one party at the expense of the total system," a statement that authors such as Murphy and Schlegelmilch (2013), and Olofsson and Söderholm (2014) consider was the first definition on the issue of CSIR. Lin-Hi and Müller (2013) point out some of these irresponsible acts, such as fixing prices, violating human rights, damaging the environment, providing inaccurate information about products, and misleading customers.

Lange and Washburn (2012) argue, however, that classifying an act of a company as socially responsible or irresponsible, is a judgment that needs to consider a set of cultural dimensions permeating society. Developing countries often find it difficult to address the issue of social responsibility because people's more basic needs (livelihood and family welfare, for instance) are at the center of the immediate attention (Martínez-Alier, 1995). In countries of greater social and economic vulnerabilities, it is not rare to see cases where society is discouraged from punishing CSIR (Bazerman \& Tenbrunsel, 2011) due to the economic benefits the corporation brings to the community (Velasquez, 2012).

The dynamic above can be observed in Brazil. This study analyzes how local citizens perceive an act of CSIR, based on the event of the rupture of the Fundão dam, in the district of Bento Rodrigues, municipality of Mariana, State of Minas Gerais. The event occurred in November 2015, and 40 municipalities in the states of Minas Gerais (MG) and Espírito Santo (ES) were affected by the disaster. The focus of the research was limited to five municipalities affected in different ways: AnchietaES, Colatina-ES, Guarapari-ES, Linhares-ES, and Mariana-MG.

The research emphasizes the citizens' feelings and judgments regarding the act of CSIR. In addition, Samarco Mineração S.A., the company responsible for the event, is controlled by the Brazilian company Vale S.A. and the Anglo-Australian BHP Billiton (Samarco Mineração S.A., 2016). The question guiding the research is:

- Does the existence of the citizen's social identification with the company, based on the economic benefits it offers to some municipalities, reduce the punitive intention against a CSIR event and blame attribution against the company?

This question led to the following objective:

- To investigate whether the social identification with the company, based on economic benefits it brings to municipalities, reduces the punitive intention and blame attribution, by using the case of Samarco Mineração S.A. in the context of the rupture of the Fundão dam. 
This research brings five main contributions to national and international literature. First, it contributes by discussing the concept of CSIR to the Brazilian context. The concept entails the relevance of assessing the behavior of Brazilian citizens when facing an act of CSIR, considering that this theme has not yet been nationally explored. The relevance of the study is even greater in localities where the population is socially identified with the company in the genesis of a disaster, considering the economic benefits the company offers. Second, this research offers an opportunity to reflect on the role of such economic benefits in the context of the company's social identification and the influence on the economic element in the citizen's attitude. Third, the study discusses how individuals, affected in different ways by acts of CSIR, perceive and evaluate them, which is a crucial contribution since there are only a few empirical studies in the area. Fourth, the findings show that given the company's economic benefits, individuals are less likely to apply a punishment, a situation that may have discouraged the parent company Vale S.A. from taking appropriate measures to avoid other disasters - such as occurred in January 2019 in the municipality of Brumadinho-MG, resulting in massive environmental and material damages, and the deaths of hundreds of people (O Portal de Notícias da Globo, 2019a). Fifth, regarding the international scenario, observing that the study refers to a developing country, the research provides subsidies to carry out future comparison studies with countries presenting different socioeconomic and cultural conditions.

\section{THEORETICAL FRAMEWORK AND HYPOTHESES}

The theme of CSIR has inspired the development of several studies throughout history, such as the works addressing consumers' willingness to punish companies involved in CSIR acts (Sweetin, Knowles, Summey, \& McQueen, 2013); exploring the relationship between CSIR and firm's performance (Kang, Germann, \& Grewal, 2016; Walker, Zhang, \& Ni, 2019); the inclination of consumers to engage in boycotts, protests, and negative word-of-mouth (WOM) against irresponsible companies (Trautwein \& Lindenmeier, 2019); the permanence and succession of executives (Chiu \& Sharfman, 2018; Oh, Chang, \& Jung, 2018); and, finally, studies on assets pricing (Lee, Lu, \& Wang, 2019).

Nevertheless, there have always been cases of companies that have been or are still "environmentally damaging," which have sold products that are harmful to health, exploited employees, or have contributed to global warming. These events occur mostly in developing countries. However, their population and governments rarely punish such companies in order to avoid future damage. The main reason is probably associated with the economic benefits of these companies, such as the increase of jobs, the stimulus to the economy, besides the contribution to the Gross Domestic Product (GDP) (Bazerman \& Tenbrunsel, 2011; George, Kuye, \& Onokala, 2012; Hilson, 2012).

Such situations also occur in developed countries, such as the United States. Some examples are the workers' exposure to asbestos and the sale of cars with manufacturing problems (Schwartz \& Carroll, 2003; Schwarze, 2003). These events imply moral conflicts, since the population is not willing to end the socially irresponsible company's activities, because they drive the economy. The rationale is that a social demand justified in the eyes of an interest group may be differently 
understood when observed through the moral lenses of managers, suppliers, customers, or other groups (Scherer \& Palazzo, 2007). This scenario of different social groups expressing themselves about an event is related to the theory of social identification, which seeks to write, prescribe, and evaluate events, generating a consensus and shared opinion by the group, forming an internal preference (Hogg, Terry, \& White, 1995).

Another theory contributing to analyze these social dynamics is the attribution theory, which aims to explain the act of blaming the responsible party for causing a harmful event. For Hamilton (1980), an event's observer may be compared both as an intuitive psychologist, who makes a judgment about the causality, and as an intuitive advocate, judging the moral responsibility. However, there are biases in judging blame attribution. Thus, many disasters that were caused by companies and brought negative consequences were perceived differently by their observers due to moral, ethical, and cultural backgrounds (Lange \& Washburn, 2012).

In the case of Samarco Mineração S.A., for example, the Municipality of Anchieta defended the continuity of the company's operation, informing the direct and indirect negative effects of paralyzing the mining activities under the company's responsibility, particularly regarding the tax collection (Prefeitura Municipal de Anchieta, 2017). The municipalities of Guarapari and Mariana also highlighted the economic importance of the mining company (Augusto, 2016; Avila, 2015). All these reports contributed to increasing the population's social identification with the firm and affected the way individuals analyze reality, as predicted in the theoretical perspective of the sociology of knowledge (Berger \& Luckmann, 1985). Given the above, it is possible to formulate the following hypothesis:

Hypothesis 1: The perception of the residents of Anchieta-ES, Colatina-ES, Guarapari-ES, Linhares-ES, and Mariana-MG about the benefits provided by Samarco Mineração S.A. for the local economy negatively affects blame attribution against the company because of the disaster in 2015 .

The next hypothesis proposes to test the theoretical relationship between blame attribution and the punitive intention regarding the disaster in Brazil. One of the highlights of this discussion is the fact that when the observer believes that the company has a low moral responsibility, the blame attribution is also low, even if there is a high perception that the company is related to the event's causality (Lange \& Washburn, 2012). Thus, different elements can influence the observers, which helps explain different assessments.

However, these differences of individual perceptions do not alter the fact that punitive intention is related to blame attribution for an event (Söderholm \& Olofsson, 2014) since there is a relationship between the equity and attribution theories. The hypothesis based on these aspects is, therefore:

Hypothesis 2: Blame attribution by the residents of Anchieta-ES, Colatina-ES, Guarapari-ES, Linhares-ES, and Mariana-MG towards Samarco Mineração S.A. because of the disaster in 2015 positively affects the intention to punish the company. 
The blame attribution would also have another impact factor, the severity perceived (Kelley \& Michela, 1980), which reinforces the idea of individual differences in the perception of corporate damage since the emotions around events are not always the same. Therefore, how rigid the blame attribution is, depends on the perception of severity (Antonetti \& Maklan, 2016a; Kelley \& Michela, 1980).

Lange and Washburn (2012) emphasize two characteristics that will draw attention to the damage: unexpectedness and concentration in time and space. Thus, unexpected events and/or highly concentrated in time and space, are usually classified as severe. Such an understanding takes into account that salient factors influence causal attribution (McArthur \& Ginsberg, 1981), which makes it possible to develop the next hypothesis:

Hypothesis 3: The evaluation of the severity of the 2015 disaster by residents of Anchieta-ES, Colatina-ES, Guarapari-ES, Linhares-ES, and Mariana-MG positively affects blame attribution from the public toward the company that caused the event, Samarco Mineração S.A.

Another point to be discussed is that social identification influences perceptions of injustice. The work by Campbell (1995) supports this understanding, showing the existence of several research threads linked to the equity theory, dealing with perceptions of equity, distributive justice, and fair prices. For the author, perceptions of injustice are based on the comparison between groups, which means that they vary among people. In addition, the environmental disaster caused by the mining company resulted in the suspension of its activities, generating unemployment and reduction of the financial movement, which can affect the punitive intention. Such observations lead to the following hypothesis:

Hypothesis 4: The perception of the residents of Anchieta-ES, Colatina-ES, Guarapari-ES, Linhares-ES, and Mariana-MG about the benefits of Samarco Mineração S.A. to the local economy, negatively affects the citizens' punitive intention for the 2015 disaster caused by the company.

The relationship between severity and punitive intention is another discussion present in CSIR. Dunford and Ridley (1996) have shown that the greater the damage, the greater the intensity of punishment. Nordgren and McDonnell (2010) also demonstrated the theoretical relationship between an event's severity and the punishment applied. Carlsmith, Darley, and Robinson (2002) discuss the existence of an expectation that the offender will be punished to the same proportion as the severity of the damage. It is important to mention that both severity and blame attribution are linked to the attribution theory and that punitive intention is related to the equity theory. The relationships among these elements lead to the following hypothesis:

Hypothesis 5: The evaluation of the severity of the disaster by residents of Anchieta-ES, Colatina-ES, Guarapari-ES, Linhares-ES, and Mariana-MG positively affects the punitive intention toward the company. 
Based on the work by Ping, Ishaq, and Li (2015), who analyzed the process of blame attribution and its influence on negative word-of-mouth (WOM), it is evident that blame attribution is among the elements preceding the intention to engage in such behavior. The studies by Richins $(1983,1987)$ demonstrate that blame attribution positively affects the expression of negative WOM, and this evidence supports the hypothesis below:

Hypothesis 6: The evaluation of blame attribution against the company by the residents of Anchieta-ES, Colatina-ES, Guarapari-ES, Linhares-ES, and Mariana-MG because of the disaster caused by Samarco Mineração S.A. in 2015 positively affects the intention to engage in negative WOM about the company.

The perception of the event's severity is a primary and needed element when it comes to the intention to engage in negative WOM. The necessity of the severity perception has been portrayed in the literature, pointing out that the greater the severity attributed to an event, the greater society's intention to engage in negative WOM will be (Antonetti \& Maklan, 2016a). This view was also advocated by Chang, Tsai, Wong, Wang, and Cho (2015), who argued that the severity of the damage causes negative comments as a reaction. These arguments find support in the attribution theory since the attribution of severity affects the intention to engage in negative WOM. The next hypothesis was built based on this dynamic:

Hypothesis 7: The evaluation of the disaster's severity by residents of Anchieta-ES, Colatina-ES, Guarapari-ES, Linhares-ES, and Mariana-MG positively affects the intention to engage in negative WOM on the company.

Finally, one of the variables preceding negative WOM is the punitive intent, since the comments are a response from society as a form of punishment. In addition, Buttle (1998) mentions three punitive actions taken by society against a company: ending the relationship, demonstrating dissatisfaction, and negative WOM. The theory behind this relationship is the equity theory since the intention to engage in negative WOM would be a response to an iniquity practiced. It is also emphasized that in situations of anger, people are more likely to punish (and make negative comments about something to others is a form of punishment). Thus, this study's last hypothesis expresses this relationship:

Hypothesis 8: The punitive intention on the part of residents of Anchieta-ES, Colatina-ES, Guarapari-ES, Linhares-ES, and Mariana-MG, related to the disaster caused by Samarco Mineração S.A. in 2015 positively affects the intention to engage in negative WOM about the company.

When taken together, these hypotheses resulted in the model introduced in this study, which relates economic benefits and CSIR (Figure 1). This model is supported by the theories presented and the empirical findings cited in this literature review. 


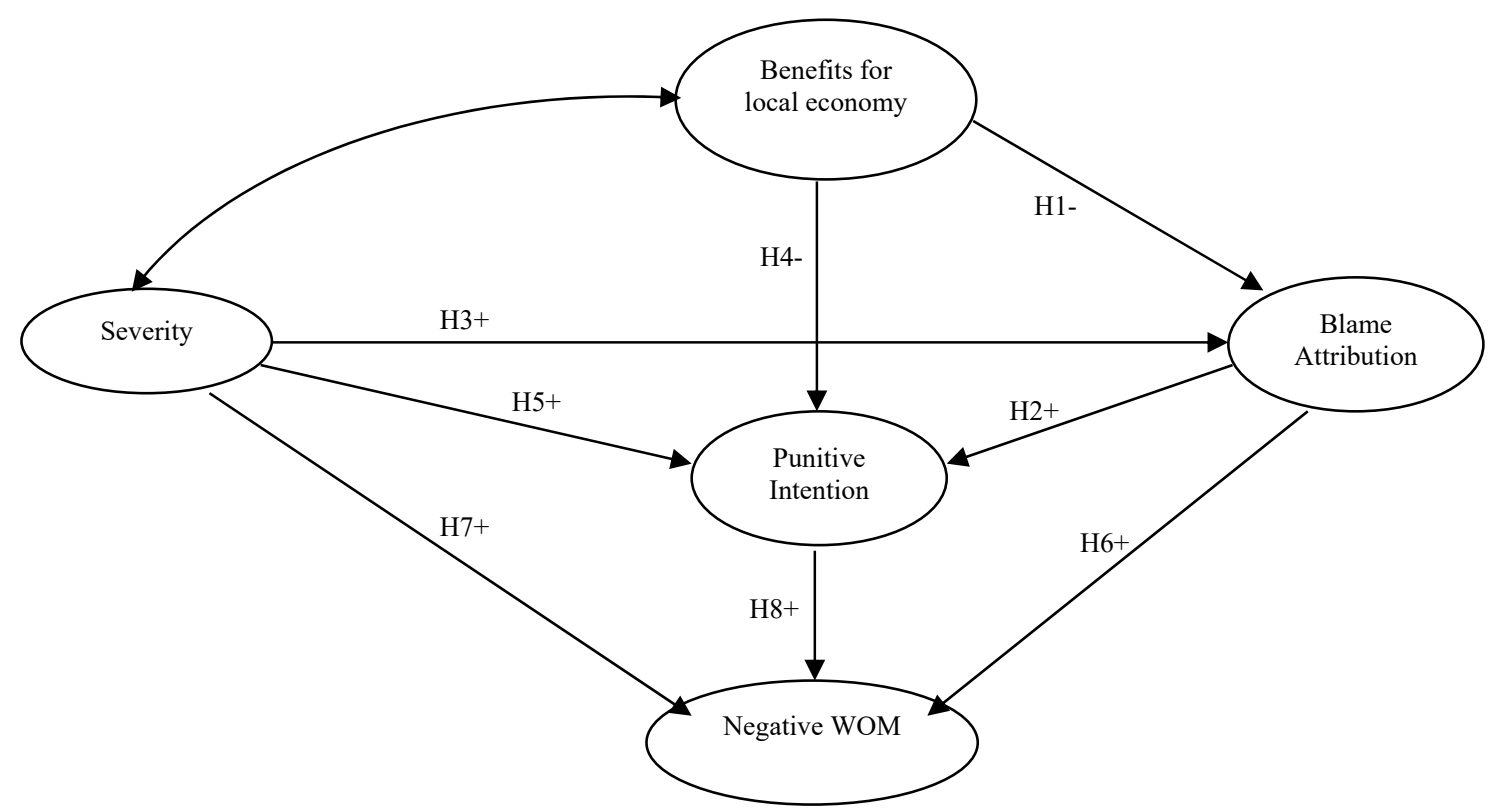

Source: Elaborated by the authors.

\section{METHOD}

The five municipalities included in the research were Anchieta-ES, Colatina-ES, Guarapari-ES, Linhares-ES, and Mariana-MG, chosen based on the way the disaster occurred in 2015 affected each one of them. The disaster did not directly impact the municipalities of Anchieta-ES and Guarapari-ES (they are located in the southern part of the State of Espírito Santo). They were affected economically because of the suspension Samarco Mineração S.A.s activities. As for Colatina-ES and Linhares-ES, located in the north of the state and crossed by the river Rio Doce (river), they have suffered the environmental impact of the disaster but were not benefited economically by the mining company. The disaster occurred in Mariana-MG. The municipality suffered both environmentally and economically as a result of the suspension of the company's activities (Augusto, 2016; Avila, 2015; Folha de S. Paulo, 2015; Gonçalves, Fusco, \& Vespa, 2016; Vignolli, 2016). Table 1 shows details of the type of benefit and the environmental effect in each municipality. 
RAP | Corporate social (ir)responsibility: an analysis of the disaster in Mariana-Brazil

\section{TABLE 1 INFORMATION ON THE MUNICIPALITIES REGARDING THE ENVIRONMENTAL DISASTER} AND THE COMPANY SAMARCO MINERAÇÃO S.A.

\begin{tabular}{|c|c|c|c|c|c|c|}
\hline Municipalities & $\begin{array}{c}\text { Type of economic } \\
\text { benefits generated } \\
\text { by Samarco } \\
\text { Mineração S.A. }\end{array}$ & $\begin{array}{c}\text { Environmental } \\
\text { disaster - Type of } \\
\text { effect }\end{array}$ & Population $^{\mathrm{a}}$ & $\begin{array}{c}\mathrm{GDP}^{\mathrm{b}} \text { (R\$ } \\
\text { Thousands) }\end{array}$ & $\begin{array}{l}\text { GDP per } \\
\text { capitab } \\
\text { (R\$) }\end{array}$ & $\begin{array}{l}\text { Primary } \\
\text { economic } \\
\text { activities }\end{array}$ \\
\hline Anchieta-ES & High & Indirect effect & 28,546 & $2,758,914$ & $99,873.80$ & $\begin{array}{l}\text { Industry (Mining), } \\
\text { family farming, } \\
\text { livestock, and } \\
\text { fishing }\end{array}$ \\
\hline Colatina-ES & None & Direct effect & 124,525 & $3,194,789$ & $26,048.87$ & $\begin{array}{l}\text { Clothing, } \\
\text { agriculture, and } \\
\text { granite }\end{array}$ \\
\hline Guarapari-ES & Medium & Indirect effect & 123,166 & $2,041,157$ & $17,037.76$ & $\begin{array}{l}\text { Commerce, } \\
\text { services, and } \\
\text { tourism }\end{array}$ \\
\hline Linhares-ES & None & Direct effect & 169,048 & $5,239,007$ & $32,011.14$ & $\begin{array}{l}\text { Industry } \\
\text { (furniture), oil and } \\
\text { gas, agriculture, } \\
\text { and livestock }\end{array}$ \\
\hline Mariana-MG & High & Direct effect & 59,857 & $3,099,191$ & $52,705.53$ & $\begin{array}{l}\text { Mining, cultural } \\
\text { tourism, and } \\
\text { commerce }\end{array}$ \\
\hline
\end{tabular}

Note: (a) Estimated for 2017; (b) 2015.

Source: Elaborated by the authors.

These municipalities were not the only ones affected. The disaster caused damages to all the cities of Minas Gerais (MG) and Espírito Santo (ES), located on the banks of the rivers Gualaxo do Norte, Rio Carmo, and Rio Doce. It is estimated that 40 municipalities were affected (Instituto Brasileiro do Meio Ambiente e dos Recursos Naturais Renováveis, 2015). Figure 2 demonstrates the extent of the event. 


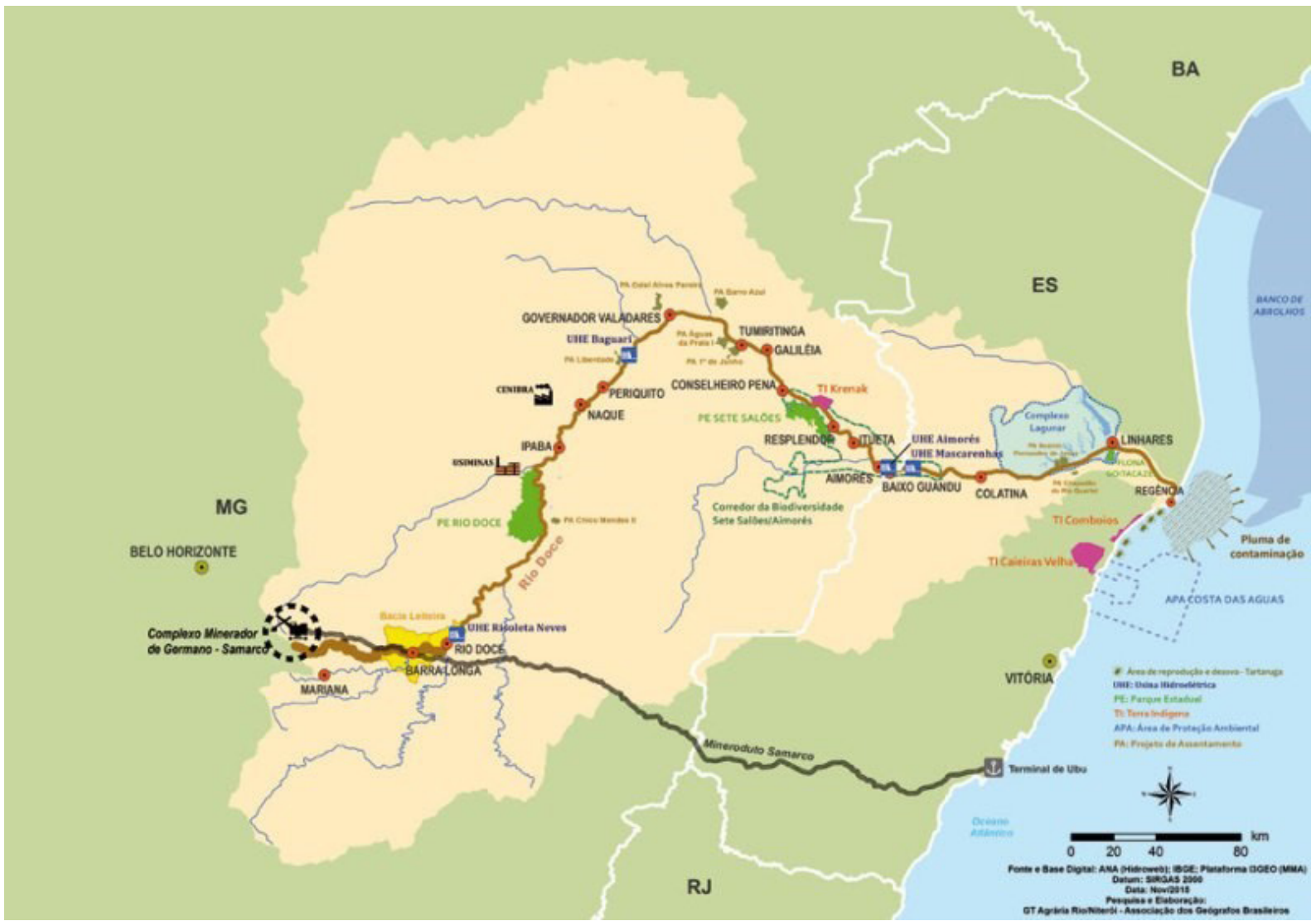

Source: Fundação Oswaldo Cruz (2016).

For the application of the research, the study adopted an instrument with psychometric scales that made it possible to measure the judgment and feeling certain individuals presented when confronted with a CSIR act. These scales were previously adopted by Antonetti and Maklan (2016a, 2016b) and Grégoire, Laufer, and Tripp (2010). As they were originally developed in English, they underwent a transcultural translation and adaptation process to follow national (Giusti \& Befi-Lopes, 2008) and international standards (Sperber, 2004). The instrument was formed with 15 items in the question format, distributed in four scales: "blame attribution," "severity," "punitive intention," and "negative word-of-mouth (WOM)."

A sample of 249 university students from a college in Guarapari-ES carried out the instruments' psychometric validation. The sample was assembled based on convenience, by the criterion of ease of access. The data factorability was tested by the indicator Kaiser-Meyer-Olkin Measure of Sampling Adequacy $(\mathrm{KMO}=0.91)$ and by Bartlett's Sphericity Test (Chi-square $=3,979.14 ; \mathrm{p}<0.001)$ (Hair, Black, Babin, Anderson, \& Tatham, 2009). Cronbach's alpha ( $\alpha$ ) was above 0.7 at all scales, and factorial loads met the generally accepted minimum of 0.32 (Tabachnick \& Fidell, 2013).

The research used another scale to measure the company's "benefits to the local economy," which was found in work by Lima (2012) and formed by seven items. Since the scale was developed in Portuguese, translation, and adaptation was not necessary in this case. 
The statistical technique used to test the model was the structural equation modeling (SEM), which "can examine a series of dependence relationships simultaneously. It is particularly useful in testing theories that contain multiple equations involving dependence relationships. [...] Thus, a hypothesized dependent variable becomes an independent variable in a subsequent dependence relationship." (Hair et al., 2009, p. 539). The hypotheses test was conducted by applying the model in each of the five municipalities, collecting a total of 1,616 questionnaires. Data collection focused on city halls, colleges, technical colleges, and schools, as well as through e-mail, sending the forms to addresses given by other respondents and searched for on social media. Table 2 presents details of the sample.

\section{TABLE 2 NUMBER OF INDIVIDUALS PER MUNICIPALITY}

\begin{tabular}{lccccc} 
Municipalities & $\begin{array}{c}\text { Individuals } \\
\text { analyzed }\end{array}$ & $\begin{array}{c}\text { Individuals excluded } \\
\text { from the sample due to } \\
\text { incomplete data }\end{array}$ & $\begin{array}{c}\text { Individuals in } \\
\text { the sample }\end{array}$ & Men & Women \\
\hline Anchieta-ES & 296 & 4 & 292 & 145 & 147 \\
Colatina-ES & 343 & 6 & 337 & 139 & 198 \\
Guarapari-ES & 284 & 3 & 281 & 132 & 149 \\
Linhares-ES & 389 & 13 & 376 & 127 & 249 \\
Mariana-MG & 335 & 5 & 330 & 154 & 175 \\
Total & 1.647 & 31 & 1.616 & $697^{*}$ & $918^{*}$ \\
\hline
\end{tabular}

* One of the individuals did not declare being man or woman, which explains the difference between the total of the sample and the sum of men and women.

Source: Elaborated by the authors.

In the SEM, the Weighted Least Squares Robust (WLSMV) method was used, based on the ordinal nature of the items. After specification and estimation of the model, its adjustment was evaluated, adopting the following indicators: chi-square, Tucker-Lewis Index (TLI), Comparative Fit Index (CFI), Root Mean Square Error of Approximation (RMSEA). The Chi-square $\left(\chi^{2}\right)$, as a criterion, should not be significant, and if it were, we adopted the chi-square ratio parameter by degrees of freedom less than 5.0. The TLI and CFI should have values ideally higher than 0.95 , and values above 0.90 are acceptable to indicate the suitability of the model to the data. Finally, we considered the cut-off point lower than 0.06 of the parsimony index of the model - RMSEA (Hu \& Bentler, 1999).

\section{RESULTS}

The exploratory analysis identified a few missing random values that were replaced by the average and, in some cases, rounded to the categories immediately following or previous, thus avoiding the creation of new categories. The descriptive analysis indicated scores close to a normal distribution.

After the exploratory analyzes, the latent structure models were tested for each of the municipalities. The SEM initial analysis showed that the model did not have a good fit in any of the cities. We then 
verified the changes suggested by the Modification Indices (MI) and obtained eight correlations among errors of items from the same scales. When analyzing the suggested modifications, the correlation of the errors was linked to the similarity in the content of some items. Thus, after the adjustments suggested by the MI, the model presented acceptable adjustment indexes (Table 3). The adjusted model led to the SEM results presented in Table 4.

\section{TABLE 3 INDICES OF THE MODELS ADJUSTED TO THE CORRELATION OF THE ERRORS}

\begin{tabular}{lccccccccc} 
Municipalities & $\begin{array}{c}\text { Observations } \\
(\mathbf{N})\end{array}$ & $\chi^{2}(\mathbf{1 7 2})$ & $\chi^{2 / d f}$ & RMSEA & $\begin{array}{c}90 \% \\
\text { Lower Cl }\end{array}$ & $\begin{array}{c}\text { Upper } \\
\text { Cl }\end{array}$ & CFI & TLI \\
\hline Anchieta-ES & 292 & $362.779^{\star * *}$ & 2.109 & 0.062 & 0.053 & 0.070 & 0.950 & 0.938 \\
Guarapari-ES & 281 & $340.952^{\star \star *}$ & 1.982 & 0.059 & 0.050 & 0.068 & 0.950 & 0.939 \\
Mariana-MG & 330 & $325.015^{\star \star *}$ & 1.890 & 0.052 & 0.043 & 0.061 & 0.969 & 0.963 \\
Colatina-ES & 337 & $349.371^{\star \star *}$ & 2.031 & 0.055 & 0.047 & 0.064 & 0.951 & 0.940 \\
Linhares-ES & 376 & $415.371^{\star \star *}$ & 2.415 & 0.061 & 0.054 & 0.069 & 0.937 & 0.923
\end{tabular}

Note: ${ }^{* *} p<0.001 ; \chi^{2}=$ chi-squared; $\mathrm{df}=$ degree of freedom; RMSEA = Root Mean Square Error of Approximation; CFI = Comparative Fit Index; TLI $=$ Tucker-Lewis Index.

Source: Elaborated by the authors.

\section{TABLE 4 RESULTS OF SEM FOR THE ADJUSTED MODEL}

\begin{tabular}{|c|c|c|c|c|c|}
\hline Construct (Standardized coefficients) & Anchieta & Guarapari & Mariana & Colatina & Linhares \\
\hline \multicolumn{6}{|l|}{ Structural model } \\
\hline Blame attribution $->$ Punitive intention $(\mathrm{H} 2+)$ & -0.352 & -0.236 & 0.245 & 0.247 & 0.228 \\
\hline Benefits local economy $\rightarrow>$ Punitive intention (H4-) & $-0.424^{\star \star \star}$ & $-0.252^{\star \star \star}$ & $-0.294^{\star \star \star}$ & -0.048 & -0.025 \\
\hline Severity $\rightarrow>$ Punitive intention ( $\mathrm{H} 5+)$ & 0.691 & 0.633 & 0.252 & 0.242 & 0.3127 \\
\hline Benefits local economy $\rightarrow>$ Blame attribution (H1-) & -0.037 & 0.030 & -0.034 & -0.032 & -0.062 \\
\hline Severity $\rightarrow>$ Blame attribution $(\mathrm{H} 3+)$ & $0.951^{\star \star \star}$ & $0.949^{\star \star \star}$ & $0.945^{\star \star \star}$ & $0.910^{\star \star \star}$ & $0.902^{\star \star \star}$ \\
\hline Punitive intention $->$ Negative WOM (H8+) & $0.786^{\star \star \star}$ & $0.923^{\star \star \star}$ & $0.972^{\star \star \star}$ & $0.819^{\star \star \star}$ & $0.829^{\star \star \star}$ \\
\hline Blame attribution -> Negative WOM (H6+) & -0.028 & -0.045 & -0.249 & -0.357 & -0.300 \\
\hline Severity - > Negative WOM (H7+) & 0.046 & 0.075 & 0.246 & 0.378 & 0.347 \\
\hline Observations & 292 & 281 & 330 & 337 & 376 \\
\hline
\end{tabular}

Note: ${ }^{* * *} p<0,001$.

Source: Elaborated by the authors. 
As for hypotheses confirmation, the analysis shows that two hypotheses ( $\mathrm{H} 3$ and $\mathrm{H} 8$ ) were supported in the five municipalities, while hypothesis 4 was supported only in Anchieta-ES, Guarapari-ES, and Mariana-MG. The other research hypotheses were not supported. These results will be discussed in the next section, in light of the literature.

\section{DISCUSSION}

This research proposes reflections on how social identification resulting from the benefits of a company to the local economy may ease feelings and intentions toward the organization, to the point of not punishing or rendering it into account for damages caused. The study explored the notion of CSIR, using a background of the environmental disaster caused by Samarco Mineração S.A. in the municipality of Mariana-MG. The objective was to understand whether social identification with the company - related to economic benefits - reduces punitive intention and blame attribution. It is possible to say that, for the municipalities researched, the perception of the event's severity increased the blame attribution, and the punitive intention increased the intention to make negative comments. In addition, the benefits the company generated to the local economy reduced the punitive intention of the residents of Anchieta-ES, Guarapari-ES, and Mariana-MG. So, in the cities where the company generated benefits, people were less prone to punish it. This reality is intriguing, as it does not encourage the company that caused damage (and its parent companies), to take measures that may prevent future disasters - such as another event that occurred a few years later, on January 25, 2019, in the municipality Brumadinho-MG, caused by Vale S.A. (O Portal de Notícias da Globo, 2019b; Schreiber, 2019).

Among the results, it is important to emphasize the confirmation of hypothesis 3 , showing that the event's severity increased blame attribution. The evidence found that this positive relation persists even in municipalities where the company generated economic benefits.

In addition, blame attribution is related to the perception of a particular event's severity (Kelley \& Michela, 1980), i.e., the damages caused by socially irresponsible companies produce negative emotions that are influenced by the severity attributed to the event (Antonetti \& Maklan, 2016a; Kelley \& Michela, 1980).

Another hypothesis supported was H4, in Anchieta-ES, Guarapari-ES, and Mariana-MG, pointing out that when the company generates economic benefits, individuals tend to have less punitive intention. In fact, this relationship proved to be stronger in Anchieta-ES, a municipality that has its largest tax revenue source in the mining company (Prefeitura Municipal de Anchieta, 2017).

Guarapari-ES, was the municipality that presented the lowest coefficient for these variables, i.e., a smaller negative relation between benefits to the local economy and the punitive intention. On the other hand, the result of this hypothesis in Mariana-MG deserves attention, considering the dimension of the environmental disaster that directly affected the region, causing destruction and death. In Mariana-MG, therefore, the economic benefits generated by Samarco Mineração S.A. reduced the punitive intention against the company among the population.

These results are in line with the findings by Lange and Washburn (2012) when arguing that individuals' social identification with a firm, may influence by minimizing reactions contrary to CSIR. Therefore, as previously expected, the residents of Anchieta-ES, Guarapari-ES, and Mariana-MG 
tended to have less punitive intention because of their social identification with the mining company, based on the economic benefits. As for Colatina-ES and Linhares-ES, the results were also congruent with expectations, considering that there was no social identification, based on direct economic benefit, with the mining company. In these municipalities, what prevailed among the population was the perception of the disaster's impact.

The third hypothesis supported was H8. The positive relation was evidenced in the five localities, confirming that the punitive intention increased the intention to engage in negative WOM. Hypotheses $\mathrm{H} 1, \mathrm{H} 2, \mathrm{H} 5, \mathrm{H} 6$, and $\mathrm{H} 7$, were not supported. This finding demonstrates that the literature predicting the relationship between the variables did not find statistical support in the case studied. The statistical evidence shows that although the benefits to the local economy negatively influence the punitive intention in Anchieta-ES, Guarapari-ES, and Mariana-MG, no evidence was found that these benefits negatively influenced blame attribution (H1). This result pointed out that even in municipalities benefited by the company, individuals did not reduce blame attribution. Also, the company did not exempt itself from the responsibility of the event.

When returning to the literature on the process of blame attribution, it is important to remember that this is a process of a social group (Lange \& Washburn, 2012). Therefore, blame attribution becomes negatively less when the observer has social identification with the company causing the damage. But this did not occur in the case of Samarco Mineração S.A. since the residents blamed the company.

However, it is significant that in none of the municipalities, blame attribution positively affected punitive intention $(\mathrm{H} 2)$. Although the theoretical framework pointed out this relationship, the hypothesis was not supported. However, some authors suggest that in several developing countries, people were less likely to punish companies due to the economic benefits the business brought to the community (Bazerman \& Tenbrunsel, 2011; Hilson, 2012). In addition, the study found that the disaster's severity did not positively influence punitive intention (H5). This finding is associated with the social and economic condition of Brazil since developing countries are considered less likely to punish a company.

The findings suggest that different social groups may perceive CSIR in different ways. When considering the population of these municipalities as social groups, it is possible to observe that they perceived the disaster differently. The difference in perception is also related to the different benefits the company generates to each municipality. Thus, the views of social groups vis-a-vis a corporation may be misaligned, especially when the company brings certain benefits for the community (Hogg et al., 1995; Scherer \& Palazzo, 2007).

Thus, considering that the perceptions of injustice or inequity are affected by the social identity, which is connected to the benefits generated, the punitive intention may be affected considering that punishment occurs if the society perceives that the company has committed some injustice. It should be noted that the variable blame attribution does not positively influence the variable negative comments (H6). This characteristic is not in line with the findings in the literature and suggests a passive behavior of the Brazilian society when it comes to the company's economic influence. Therefore, the severity variable (H7) did not positively influence the variable negative WOM. This observation shows that the sample behaves differently from what was supported in work by Antonetti and Maklan (2016a). The finding for these municipalities suggests that this behavior, which is different from what the literature has shown in other countries, may repeat in other regions of Brazil. 
Therefore, it is possible to conclude that the economic benefit offered by the company had little impact on blame attribution, but affected the punitive intention. This finding complements the results pointed out by Antonetti and Maklan (2016a, 2016b), since they did not explore the effects of economic benefits on blame attribution and punitive intent.

The case of Samarco Mineração S.A. has similarities with the experience of Shell. The oil company had spilled oil in the Niger Delta for decades, but its activities were not suspended due to the company's impact on the Nigerian GDP (George et al., 2012). Likewise, Samarco Mineração S.A. made it clear its economic importance to the Brazilian states of Minas Gerais and Espírio Santo soon after the environmental disaster of Mariana-MG (Samarco Mineração S.A., 2016). This information was also confirmed when 3.9\% of Espírito Santo GDP fell, in addition to the reduction in Minas Gerais GDP, attributed to the suspension of the activities of the company (Fundação João Pinheiro, 2016; O Portal de Notícias da Globo, 2016). Thus, the affected states suffered not only from the dam's rupture and the residues spilled but also from the economic impact as a consequence of the suspension of the firm's activities.

In this sense, it is understandable that the result points to attribution of blame to Samarco Mineração S.A., but this attribution does not influence negative WOM and punitive intention. Thus, while on the one hand, the population of the five municipalities recognizes the company's blame for the damages of the environmental disaster; on the other, there is no punitive intention, possibly for fear that this will affect the economy, as happened in other environmental accidents around the world (George et al., 2012; Hilson, 2012). This reality may have influenced both the company and its parent companies Vale S.A. and BHP Billiton not to take measures to avoid future disasters such as that which occurred in January 2019 in Brumadinho-MG.

\section{CONCLUSION}

Although the theme of CSIR has been discussed for years, the subject is not usually presented explicitly in the literature on CSR (Lange \& Washburn, 2012). The Brazilian literature has shown little study on CSIR, which has instigated this research. The purpose of this study was to determine whether the social identification with Samarco Mineração S.A., based on the economic benefits the company offers, reduces punitive intention and blame attribution against the company due to the environmental disaster it caused.

The study concluded that in the cities where the mining company generated jobs and benefited the economy (Anchieta-ES, Guarapari-ES, and Mariana-MG), the population had a greater perception of benefits, negatively affecting the punitive intention. On the other hand, the perception of benefits to the economy in these three cities did not negatively affect blame attribution. One of the explanations of this finding was that, by using impression management strategies, the company did not seek to escape responsibility. However, it made clear how much it contributed to the economy of Espírito Santo and Minas Gerais states, and the actions that would be taken to overcome the disaster (Samarco Mineração S.A., 2016, 2018).

In addition, blame attribution by the researched population did not positively affect the punitive intention against the company. It should be noted that the Brazilian perception of punishment is somewhat impaired due to disbelief in the national judicial system (Reichenheim et al., 2011). In 
addition, developing countries usually pay little attention to problems related to pollution (Surroca, Tribo, \& Zahra, 2013).

Regarding the evaluation of the severity of the event, this perception positively affected blame attribution also in the tests in locations where the company's economic contribution was significant. However, there was no evidence that the evaluation of the event's severity affected the punitive intention against the company. Although there is theoretical evidence that reports the existence of this relationship, it was not confirmed by the research.

Consequently, no evidence was found that the blame attribution positively affected the intention to engage in negative WOM against the mining company. Also, if the blame attribution did not positively affect the punitive intention, the expectation was that the blame attribution would not affect the intention to engage in negative WOM, considering that this behavior may also be considered a punishment (Buttle, 1998). In addition, the evaluation of severity did not positively affect the intention to engage in negative WOM against the company.

The study found that the punitive intention of the population positively affected the intention to engage in negative WOM. These results are aligned with the theoretical evidence (Buttle, 1998). All these findings have opened space for future research seeking to evaluate feelings, judgments, and attributions that may be observed in disasters caused by companies.

As for the limitations, this research was carried out in a single moment, which may have increased the possibility of bias in the results. Another point is that the evaluations are restricted to a single event, and the sample represents the opinion collected in five municipalities. Therefore, it is not possible to generalize the results for other events and localities.

Based on the elements presented in this article and considering that the theme of CSIR is recent in Brazil, it is possible to observe the need to expand the research agenda in future studies. Qualitative approaches using interviews and focus groups are recommended to challenge the results obtained in this research, contributing to increasing the knowledge on the issue. Also, considering the findings obtained here, future research may discuss the understanding of blame and punishment, given that in the cities of Anchieta-ES, Guarapari-ES, and Mariana-MG, the economic benefits related to Samarco's operations negatively influenced the punitive intention. Moreover, such qualitative research could also emphasize the debate about the company's guilt and whether it should be punished. It could also discuss what kind of punishment should be adopted.

Quantitative studies considering other events and companies related to the issue of CSIR would be useful to test the structure proposed in this research. Also, other elements that may predict people's judgment about acts of CSIR could be tested, such as education, level of damage caused, age, family income. It is also suggested that studies continue to investigate acts of CSIR by other companies or in other places, such as the recent environmental disaster of January 2019 in Bumadinho-MG, comparing the new results with those evidenced here. Finally, longitudinal studies following affected populations periodically may be a useful form of evaluating the several aspects related to CSIR and environmental disasters. 


\section{REFERENCES}

Alexander, P. B. (2015). Corporate social irresponsibility. New York, NY: Routledge.

Antonetti, P., \& Maklan, S. (2016a). An Extended Model of Moral Outrage at Corporate Social Irresponsibility. Journal of Business Ethics, 135(3), 429-444.

Antonetti, P., \& Maklan, S. (2016b). Social identification and corporate irresponsibility: a model of stakeholder punitive intentions. British Journal of Management, 27(3), 583-605.

Armstrong, J. S. (1977). Social irresponsibility in management. Journal of Business Research, 5(3), $185-213$.

Augusto, L. (2016). Prefeito de Mariana se reúne com Temer para pedir volta da Samarco. Retrieved from http://brasil.estadao.com.br/noticias/geral,prefeitode-mariana-se-reune-com-temer-para-pedirretorno-da-samarco-a-cidade, 10000054576

Avila, G. (2015). Guarapari pode sofrer impacto de $R \$ 12$ milhões com paralisação da Samarco. Retrieved from https://www.portal27.com.br/guarapari-podesofrer-impacto-de-r-12-milhoes-com-paralisacaoda-samarco/

Bazerman, M. H., \& Tenbrunsel, A. E. (2011). Blind spots: why we fail to do what's right and what to do about it. Princeton, NJ: Princeton University Press.

Berger, P. L., \& Luckmann, T. (1985). Construção social da realidade: tratado de sociologia do conhecimento. Petrópolis, RJ: Vozes.

Buttle, F. A. (1998). Word of mouth: understanding and managing referral marketing. Journal of Strategic Marketing, 6(3), 241-254.

Campbell, M. C. (1995). When attention-getting advertising tactics elicit consumer inferences of manipulative intent: the importance of balancing benefits and investments. Journal of Consumer Psychology, 4(3), 225-254.

Carlsmith, K. M., Darley, J. M., \& Robinson, P. H. (2002). Why do we punish? Deterrence and just deserts as motives for punishment. Journal of Personality and Social Psychology, 83(2), 284-299.

Chang, H. H., Tsai, Y.-C., Wong, K. H., Wang, J. W., $\&$ Cho, F. J. (2015). The effects of response strategies and severity of failure on consumer attribution with regard to negative word-of-mouth. Decision Support Systems, 71, 48-61.

Chiu, S.-C., \& Sharfman, M. (2018). Corporate social irresponsibility and executive succession: an empirical examination. Journal of Business Ethics, 149(3), 707-723.

Dunford, L., \& Ridley, A. (1996). No soul to be damned, no body to be kicked": responsibility, blame and corporate punishment. International Journal of the Sociology of Law, 24, 1-19. Retrieved from http://www.sciencedirect.com/science/article/pii/ S0194659596900015

Folha de S. Paulo. (2015). O caminho da lama. Retrieved from http://temas.folha.uol.com.br/ocaminho-da-lama/

Fundação João Pinheiro. (2016). PIB de Minas Gerais expande 0,1\% no segundo trimestre de 2016. Retrieved from http://www.fjp.mg.gov.br/index.php/ noticias-em-destaque/3644-pib-de-minas-geraisexpande-0-1-no-segundo-trimestre-de-2016

Fundação Osvaldo Cruz. (2016). Cenário de fim do mundo no rastro da lama. Retrieved from http:// www.epsjv.fiocruz.br/noticias/reportagem/cenariode-fim-do-mundo-no-rastro-da-lama

George, O. J., Kuye, O. L., \& Onokala, U. C. (2012). Corporate social irresponsibility (CSI) a catalyst to the Niger Delta crisis: the case of Nigerian oil multinational companies versus the militants of Niger Delta Region of Nigeria. Journal of Management Research, 4(2), 1-11.

Giusti, E., \& Befi-Lopes, D. M. (2008). Tradução e adaptação transcultural de instrumentos estrangeiros para o português brasileiro (PB). Pró-Fono Revista de Atualização Científica, 20(3), 207-210.

Gonçalves, E., Fusco, N., \& Vespa, T. (2016). Tragédia em Mariana: para que não se repita. Retrieved from http://veja.abril.com.br/complemento/brasil/paraque-nao-se-repita/

Grégoire, Y., Laufer, D., \& Tripp, T. M. (2010). A comprehensive model of customer direct and indirect revenge: understanding the effects of perceived greed and customer power. Journal of the Academy of Marketing Science, 38(6), 738-758. 
Hair, J. F., Jr., Black, W. C., Babin, B. J., Anderson, R. E., \& Tatham, R. L. (2009). Análise multivariada de dados (6th ed.). Porto Alegre, RS: Bookman.

Hamilton, V. L. (1980). Intuitive psychologist or intuitive lawyer? Alternative models of the attribution process. Journal of Personality and Social Psychology, 39(5), 767-772.

Hilson, G. (2012). Corporate social responsibility in the extractive industries: experiences from developing countries. Resources Policy, 37(2), 131-137.

Hogg, M. A., Terry, D. J., \& White, K. M. (1995). A tale of two theories: a critical comparison of identity theory with social identity theory. Social Psychology Quarterly, 58(4), 255-269.

Hu, L., \& Bentler, P. M. (1999). Cutoff criteria for fit indexes in covariance structure analysis: conventional criteria versus new alternatives. Structural Equation Modeling: A Multidisciplinary Journal, 6(1), 1-55.

Instituto Brasileiro do Meio Ambiente e dos Recursos Naturais Renováveis. (2015). Laudo técnico preliminar: impactos ambientais decorrentes do desastre envolvendo o rompimento da barragem de Fundão, em Mariana, Minas Gerais. Retrieved from http://www.ibama.gov.br/phocadownload/noticias_ ambientais/laudo_tecnico_preliminar_Ibama.pdf

Kang, C., Germann, F., \& Grewal, R. (2016). Washing away your sins? Corporate social responsibility, corporate social irresponsibility, and firm performance. Journal of Marketing, 80(2), 59-79.

Kelley, H. H., \& Michela, J. L. (1980). Attribution theory and research. Annual Review of Psychology, 31(1), 457-501.

Kotchen, M., \& Moon, J. J. (2012). Corporate social responsibility for irresponsibility. The B.E. Journal of Economic Analysis \& Policy, 12(1), 1-21.

Lange, D., \& Washburn, N. T. (2012). Understanding attributions of corporate social irresponsibility. Academy of Management Review, 37(2), 300-326.

Lee, Y.-C., Lu, Y.-C., \& Wang, Y.-C. (2019). Corporate social irresponsibility, CEO overconfidence, and stock price crash risk. Applied Economics Letters, 26(14), 1143-1147.

Lima, S. C. M. (2012). As perceções dos residentes do papel do turismo no desenvolvimento da Ilha da
Boavista. Retrieved from https://estudogeral.sib. uc.pt/bitstream/10316/19786/4/As perceções dos residentes do papel do turismo.pdf

Lin-Hi, N., \& Müller, K. (2013). The CSR bottom line: preventing corporate social irresponsibility. Journal of Business Research, 66(10), 1928-1936.

Martínez-Alier, J. (1995). The environment as a luxury good or "too poor to be green"? Ecological Economics, 13(1), 1-10.

McArthur, L. Z., \& Ginsberg, E. (1981). Causal attribution to salient stimuli: an investigation of visual fixation mediators. Personality and Social Psychology Bulletin, 7(4), 547-553.

Murphy, P. E., \& Schlegelmilch, B. B. (2013). Corporate social responsibility and corporate social irresponsibility: introduction to a special topic section. Journal of Business Research, 66(10), 1807-1813.

Nordgren, L. F., \& McDonnell, M.-H. M. (2010). The scope-severity paradox: why doing more harm is judged to be less harmful. Social Psychological and Personality Science, 2(1), 97-102.

O Portal de Notícias da Globo. (2016, June 20). PIB cai 3,9\% no $2^{\circ}$ trimestre e ES liga resultado a Samarco e seca. Retrieved from http://g1.globo.com/espiritosanto/noticia/2016/09/pib-cai-39-no-2-trimestre-ees-liga-resultado-samarco-e-seca.html

O Portal de Notícias da Globo. (2019a, January 25). Rompimento de barragem de rejeitos de minério provoca desastre em Brumadinho (MG). Retrieved from https://g1.globo.com/jornal-nacional/ noticia/2019/01/25/rompimento-de-barragemde-rejeitos-de-minerio-provoca-desastre-embrumadinho-em-minas-gerais.ghtml

O Portal de Notícias da Globo. (2019b, April 10). Sobe para 225 o número de mortos identificados no desastre da Vale em Brumadinho. Retrieved from https:// g1.globo.com/mg/minas-gerais/noticia/2019/04/10/ sobe-para-225-o-numero-de-mortos-identificadosno-desastre-da-vale-em-brumadinho.ghtml

Oh, W.-Y., Chang, Y. K., \& Jung, R. (2018). Experience-based human capital or fixed paradigm problem? CEO tenure, contextual influences, and corporate social (ir)responsibility. Journal of Business Research, 90, 325-333. 
Olofsson, J., \& Söderholm, L. (2014). The effect of corporations' irresponsible actions on young consumers' purchasing behavior in the FMCG apparel industry. Retrieved from http://www.diva-portal. org/smash/get/diva2:728818/FULLTEXT03.pdf

Ping, Q., Ishaq, M., \& Li, C. (2015). Product harm crisis, attribution of blame and decision making: an insight from the past. Journal of Applied Environmental and Biological Sciences, 5(5), 35-44.

Popa, M., \& Salanță, I. (2014). Corporate social responsibility versus corporate social irresponsibility. Management and Marketing. Challenges for the Knowledge Society, 9(2), 137-146. Retrieved from http://www.managementmarketing.ro/pdf/ articole/446.pdf

Prefeitura Municipal de Anchieta. (2017). História e perfil de Anchieta. Retrieved from http://www. anchieta.es.gov.br/materia_especifica/6495/historiae-perfil-de-anchieta

Reichenheim, M. E., Souza, E. R. de, Moraes, C. L., Jorge, M. H. P. de M., Silva, C. M. F. P. da, \& Minayo, M. C. de S. (2011). Violence and injuries in Brazil: the effect, progress made, and challenges ahead. The Lancet, 377(9781), 1962-1975.

Richins, M. L. (1983). Negative word-of-mouth by dissatisfied consumers: a pilot study. Journal of Marketing, 47(1), 68-78.

Richins, M. L. (1987). A multivariate analysis of responses to dissatisfaction. Journal of the Academy of Marketing Science, 15(3), 24-31.

Samarco Mineração S.A. (2016). Dossiê Samarco. Samarco Mineração S.A. Retrieved from http:// www.samarco.com/wp-content/uploads/2015/12/ Dossie_reduzido_19_05.pdf

Samarco Mineração S.A. (2018). Entenda o rompimento. Retrieved from http://www.samarco. com/rompimento-de-fundao/

Scherer, A. G., \& Palazzo, G. (2007). Toward a political conception of corporate responsibility: business and society seen from a Habermasian perspective. Academy of Management Review, 32(4), 1096-1120.

Schreiber, M. (2019). Tragédia em Brumadinho: quase três anos após desastre de Mariana, Vale ofereceu $R \$ 30$ mi em bônus recorde a seis diretores executivos. Retrieved from https://www.bbc.com/ portuguese/brasil-47095802

Schwartz, M. S., \& Carroll, A. B. (2003). Corporate social responsibility: a three-domain approach. Business Ethics Quarterly, 13(4), 503-530.

Schwarze, S. (2003). Corporate-state irresponsibility, critical publicity, and asbestos exposure in Libby, Montana. Management Communication Quarterly, 16(4), 625-632.

Sperber, A. D. (2004). Translation and validation of study instruments for cross-cultural research. Gastroenterology, 126(1), S124-S128.

Surroca, J., Tribo, J. A., \& Zahra, S. A. (2013). Stakeholder pressure on MNEs and the transfer of socially irresponsible practices to subsidiaries. Academy of Management Journal, 56(2), 549-572.

Sweetin, V. H., Knowles, L. L., Summey, J. H., \& McQueen, K. S. (2013). Willingness-to-punish the corporate brand for corporate social irresponsibility. Journal of Business Research, 66(10), 1822-1830.

Tabachnick, B. G., \& Fidell, L. S. (2013). Using multivariate statistics (6th ed.). Upper Saddle River, NJ: Pearson Education.

Trautwein, S., \& Lindenmeier, J. (2019). The effect of affective response to corporate social irresponsibility on consumer resistance behaviour: validation of a dual-channel model. Journal of Marketing Management, 35(3-4), 253-276.

Velasquez, M. G. (2012). Business ethics: concepts and cases (7th ed.). Upper Saddle River, NJ: Pearson Education.

Vignolli, E. (2016, April 08). Empresários de Anchieta querem a volta da Samarco no ES: eles dizem que paralisação gerou desemprego e queda no faturamento. O Portal de Notícias da Globo. Retrieved from http://g1.globo.com/espirito-santo/ noticia/2016/04/empresarios-de-anchieta-queremvolta-da-samarco-no-es.html

Walker, K., Zhang, Z., \& Ni, N. (2019). The mirror effect: corporate social responsibility, corporate social irresponsibility and firm performance in coordinated market economies and liberal market economies. British Journal of Management, 30(1), 151-168. 


\section{Mirian Albert Pires}

https://orcid.org/0000-0001-8975-9280

Ph.D. in Administration and Adjunct Professor in the Department of Accounting at the Federal University of Espírito Santo (UFES). E-mail: mirian.pires@ufes.br

\section{Luciana Mourão}

https://orcid.org/0000-0002-8230-3763

Ph.D. in Psychology and Professor of the Graduate Program in Psychology at Salgado de Oliveira University (UNIVERSO).E-mail: mourao.luciana@gmail.com

\section{Fátima Bayma de Oliveira}

iD

https://orcid.org/0000-0001-5158-9546

Ph.D. in Education and Professor at the Brazilian School of Public and Business Administration of Fundação Getulio Vargas (FGV EBAPE). E-mail: fatima.oliveira@fgv.br

\section{Jose Antonio Puppim de Oliveira}

https://orcid.org/0000-0001-5000-6265

Ph.D. em Planejamento (MIT); Professor of Fundação Getulio Vagas, at the São Paulo School of Business Administration (FGV EAESP) and at the Brazilian School of Public and Business Administration (FGV EBAPE).E-mail: jose.puppim@fgv.br 